Veljko Dmitrovic ${ }^{1}$, Marina Dobrota'1, Snezana Knezevic ${ }^{1}$

1 University of Belgrade, Faculty of Organizational Sciences

\title{
A Statistical Approach to Evaluating Bank Productivity
}

UDC: 005.61:336.71(497.11)

005.311 .121

DOI: 10.7595/management.fon.2015.0010

\begin{abstract}
Since 2001, when a new cycle in the process of economic transition was vigorously launched in the country, the Serbian banking sector has incurred deep changes. This issue has acutely affected the banking sector in Serbia proper, directly influencing its performance and efficiency. This paper deals with the application of a new statistical approach - the I-distance method - in measuring the financial performance of banks that do business in Serbia in order to determine their productivity level, thus stressing the performance of banks from the perspective of productivity. Additionally, this point of view is essential for projecting productivity in evaluating overall bank operation efficiency.
\end{abstract}

Keywords: banks, efficiency, productivity, I-distance method, ranking

\section{Introduction}

In the times of economic crises, the banking sector was an issue of discussion worldwide (Houston et al., 2010; Chiorazzo \& Milani, 2011; Maggi \& Guida, 2011; Claessens \& van Horen, 2012). The financial crisis led to a reemergence of the debates and the issue became even more critical since the current crisis challenged most of the conventional wisdom regarding the design and use of monetary policy (Caraiani, 2011). For instance, Wu, Yang and Liang (2006) stress that analyzes in service industries attract increasing attention in today's economics and society. We should add that this fact is even more apparent in conditions of economic crisis. It is also well established that when it is difficult to increase income significantly, attention is rather focused on rational cost management, as well as on increasing the productivity and efficiency of financial and other institutions.

A similar situation has befallen Serbia (Bulajic, Savic, \& Savic, 2012). Since 2001, the Serbian banking sector has incurred deep changes, when a new cycle in its economic transition process was forcefully launched. Hence the necessity to continually evaluate and measure the performance and efficiency of its banking sector.

Efficiency is a success indicator (Park \& Cho, 2011; Koutsomanoli-Filippaki, Margaritis, \& Staikouras, 2012; Zhang, Wang \& Qu, 2012). It demonstrates the degree of effectiveness of banks that take specific inputs (deposits, borrowings, assets employment, etc.) to obtain outputs (revenue, profits, etc.). To adequately analyze a bank's efficiency, it is particularly important to select appropriate combinations of inputs and outputs. Relevant academic literature has presented different possibilities of combining inputs and outputs to test the efficiency of a bank (Kasman, Kasman, \& Turgutlu, 2011; Hadad et al., 2012). Under conditions of the current economic crisis (Wu, Luca \& Jeon, 2011), it is crucial to monitor the efficiency of banks. For developing countries (Tecles \& Tabak, 2010; Olson \& Zoubi, 2011; Benkovic \& Dobrota, 2012), it is especially important to monitor the efficiency of the accounting periods for domestic banks and compare them with those of foreign banks in the region (Yudistira, 2003; Shin \& Kim, 2011; Uludag \& Gokmen, 2011; Huang, Chiang, \& Chen, 2011).

One aspect of monitoring a bank's efficiency is the analysis of its productivity.

The effective managing of bank productivity includes monitoring the bank in three segments: 
- in relation to its planned size;

- in relation to the achievements of other banks in the banking sector;

- in comparison with the leader of the banking sector:

Productivity is an important instrument for increasing the overall efficiency of banks (Andries, 2011). Fixler and Zieschang (1999), concerned with measuring the output of the banking sector, stress that banking output is multidimensional and in these terms it is necessary to underline the complexity of the application of economic statistics and productivity models. In a work by Kirikal (2005), an empirical study measuring the productivity of Estonian banks was shown. Fiordelisi and Molyneux (2010) examined shareholder value drivers in European banking by focusing on the efficiency and productivity of individual banks, utilizing French, Italian, UK and German banking systems for the years 1995 - 2002 as their sample. In addition, many authors in South-eastern Europe have used different methods to measure bank productivity. For instance, Roghanian, Rasli, and Gheysari (2012) examined productivity through effectiveness and efficiency in the banking industry, concentrating on identifying a precise position of productivity via an effectivenessefficiency matrix.

In order to measure a bank's productivity, various techniques can be used. One of them is ratio analysis, which measures a bank's productivity based on financial information. Such indicators of productivity could include:

- the relationship between bank's assets and the number of employees

- the relationship between a bank's net interest margin and the number of employees

- the relationship between a bank's total revenue and total hours of work

- the relationship between a bank's profit before tax ratio and its total number of bank employees (Knezevic et al., 2011)

The financial performance of banks is necessary to be tracked and analyzed (Festic \& Kavkler, 2012). It has been measured using a combination of financial ratio analysis, benchmarking, and measuring performance against a bank's budget or an amalgam of these methodologies (Avkiran, 1995). However, the use of ratio analysis is a one-sided approach, or, rather, a partial indicator of efficiency. Therefore, other techniques for measuring the efficiency of banks, such as various statistical methods (Dobrota, Jeremic, \& Markovic, 2012; Horvat et al., 2013), the DEA (Data Envelopment Analysis) method (Dekker \& Post, 2001; Liu, 2009; Paradi, Rouatt, \& Haiyan, 2011), the Malmquist's index method (Primorac \& Troskot, 2005; Kirikal, 2005), or the Idistance method (Knezevic et al., 2011) may also be used.

The following section explains the problem definition in detail, followed by method elaboration in Section 3. A presentation of the results and a robust discussion are given in Section 4. Finally, some concluding remarks are provided.

\section{Problem Definition}

This paper attempts to analyze the efficiency of banks in the Serbian banking sector exclusively from the perspective of productivity. For this matter, a number of input variables have been defined, which are measured as the values of the original variables divided by the number of a bank's employees. Data gathered from 2010 have been used, the latest available.

Partial efficiency indicators of entities are 1) productivity, 2) cost effectiveness, 3) profitability. Productivity in this paper is examined through work productivity, which represents the relationship between the financially quantified bank performance and the number of employees in the bank.

The statistical I-distance method has been used to research this problem. The issue at hand is to use a single comprehensive methodology that will define a set of variables relevant to the analysis. Based on the correlation between the criteria and the I-distance measure, the I-distance method provides a proper overview of the importance of input measures and, subsequently, the order of importance for input criteria as it can be determined. Thereby, this method provides an answer to the question of which variables are most important in measuring a bank's efficiency from the perspective of productivity. 
An important matter in analyzing bank efficiency is the careful selection of the input variables used. For instance, when examining the efficiency and productivity of banks in descriptive European banking statistics, Fiordelisi and Molyneux (2010) utilized the following variables: EVA/CI, ROA, ROE, Total Assets, Total Deposits and Total Loans. The precise nature of banking services complicates the process of measuring productivity: in the total costs of the bank, labor costs have a high share. Among the subjective factors that have a substantial impact on productivity, the bank's management and qualified and motivated bank personnel are singled out. Variables for productivity indicators were selected as relevant since they are the principal financial performances, also presenting contribution of employees to the overall productivity of the bank by their height depending largely on the capacity of the bank personnel. Therefore they may be brought to direct connection with the performance on the basis of the information presented in the annual report and in internal reports created by the management accountants for the purpose of measuring performance by narrower organizational departments of the bank.

\subsection{Financial Data}

For this paper here on the Serbian banking sector, the input variables have been carefully chosen so that they should not be excessively correlated, yet still be sufficiently explanatory. According to these terms, the variables that have been used as input criteria, as well as the reasons for choosing these particular variables, have been listed below. All the input variables are divided by the bank's number of employees in order to observe the banking efficiency issue solely from a perspective of productivity:

- Assets per Employee - Composed of non-current (fixed) and current assets, these are the total assets a bank owns, which it uses to achieve its business goals.

- Equity per Employee - The equity's height indicates which parts of the bank's assets are financed by its capital. Equity is defined as the security for the bank's depositors and creditors.

- Earnings before Tax (EBT) per Employee - Pre-tax profit, the positive difference between the total revenue and total expenses for the bank's accounting period (usually one year). It indicates the bank's strength of profitability.

- Fees and Commissions Income (F\&Cl) per Employee - The income from fees and commissions charged by a bank for its services. In addition to interest, income represents key essential business income for both the survival of a bank and its long-term success.

- Net Fees and Commissions Income (NF\&Cl) per Employee - The difference between a bank's income from fees/commissions and its expenses. These are the investments that management has made to provide services that are classified as revenue noted above.

- Total Net Income (TNI) per Employee - The difference between a bank's total interest income and interest expense. It is important for this variable to be positive since interest is one of the main generators of income for banks as financial institutions.

- Total Income (TI) per Employee - Indicates the revenue power of a bank as it synthesizes the total interest income, fee income and commissions gained on the sale of equity investments and other long-term investments, income from exchange rate differences and other sources of income. This variable is highly important in determining the profitability of income.

These variables have been selected as best to measure bank efficiency as they intentionally indicate the productivity of resources used by banks through the various forms of the financial results of their operations.

\subsection{I-distance Method}

Quite often the ranking of entities is affected by the ranking methodology (Ivanovic, 1973; Ivanovic \& Fanchette, 1973; Radojicic \& Jeremic, 2012). The I-distance method can solve this problem as elaborated in literature review (Jeremic et al., 2011; Radojicic \& Jeremic, 2012; Jovanovic et al., 2012; Isljamovic et al., 2014; Seke et al., 2013; Jeremic et al., 2013; Jeremic \& Jovanovic-Milenkovic, 2014; Jovanovic-Milenkovic, Jeremic, \& Martic, 2014; Dobrota et al., in press).

For a selected set of variables $X^{T}=\left(X_{1}, X_{2}, \ldots, X_{k}\right)$ that characterize the entities, the I-distance between the two entities $e_{r}=\left(x_{1 r}, x_{2 r}, \ldots, x_{k r}\right)$ and $e_{s}=\left(x_{1 s}, x_{2 s}, \ldots, x_{k s}\right)$ is defined as 


$$
D(r, s)=\sum_{i=1}^{k} \frac{\left|d_{i}(r, s)\right|}{\sigma_{i}} \prod_{j=1}^{i-1}\left(1-r_{j i .12 \ldots j-1}\right)
$$

where $d_{i}(r, s)$ is the distance between the values of variable $X_{i}$ for $e_{r}$ and $e_{s}$, e.g., the discriminate effect, $\sigma_{i}$ is the standard deviation of $X_{i}$ and $r_{j i .12 \ldots j-1}$ is a partial coefficient of the correlation between $X_{i}$ and $X_{j},(j<i)$, (Ivanovic, 1973; Jeremic, Markovic, \& Radojicic, 2011; Jeremic et al., 2012; Dobrota, Jeremic, \& Markovic, 2012).

For the purpose of this analysis, we have used the square I-distance method, which can be presented by the following expression:

$$
D^{2}(r, s)=\sum_{i=1}^{k} \frac{d_{i}^{2}(r, s)}{\sigma_{i}^{2}} \prod_{j=1}^{i-1}\left(1-r_{j i .12 \ldots j-1}^{2}\right)
$$

\section{Results and Discussion}

The results of the I-distance method used to measure and rank bank efficiency are displayed in Table 1. As can be seen, if efficiency were to be measured from the point of productivity, than AlK Bank, UniCredit Bank, Banca Intesa, Hypo-Alpe-Adria Bank, Volks Bank and Raiffeisen bank would find themselves foremost on the ranking list. On the other hand, KBC Bank, Srpska bank, Vojvodjanska bank, Opportunity Bank and Dunav bank would be located at the bottom.

\begin{tabular}{|c|c|c|}
\hline Bank & I-distance & I-distance Rank \\
\hline AlK Bank & 53.773 & 1 \\
\hline UniCredit Bank & 15.64 & 2 \\
\hline Banca Intesa & 14.648 & 3 \\
\hline Hypo-Alpe-Adria Bank & 14.192 & 4 \\
\hline Volks Bank & 13.554 & 5 \\
\hline Raiffeisen Bank & 10.019 & 6 \\
\hline Societe Generale & 9.906 & 7 \\
\hline EFG Eurobank & 8.909 & 8 \\
\hline Postanska stedionica & 7.505 & 9 \\
\hline Agrobank & 6.602 & 10 \\
\hline Moskovska Bank & 6.229 & 11 \\
\hline Komercijalna Bank & 6.015 & 12 \\
\hline Univerzal Bank & 5.943 & 13 \\
\hline Erste Bank & 5.424 & 14 \\
\hline NLB Bank & 5.36 & 15 \\
\hline Cacanska Bank & 4.946 & 16 \\
\hline RB Vojvodine & 4.448 & 17 \\
\hline JUBMES Bank & 4.431 & 18 \\
\hline PB Beograd & 4.059 & 19 \\
\hline ProCredit Bank & 3.079 & 20 \\
\hline Piraeus Bank & 3.069 & 21 \\
\hline Credit Agricole Bank & 2.829 & 22 \\
\hline OTP Bank & 2.33 & 23 \\
\hline Findomestic Bank & 2.088 & 24 \\
\hline Alpha Bank & 1.488 & 25 \\
\hline Jugobank & 1.186 & 26 \\
\hline Credy Bank & 1.168 & 27 \\
\hline Marfin Bank & 1.153 & 28 \\
\hline KBC Bank & 1.124 & 29 \\
\hline Srpska Bank & 1.116 & 30 \\
\hline Vojvodjanska Bank & 1.04 & 31 \\
\hline Opportunity Bank & 0.721 & 32 \\
\hline Dunav Bank & 0.501 & 33 \\
\hline
\end{tabular}

Table1 1: I-distance rank 
One of the most significant advantages of the I-distance method is its ability to determine the relevance of input criteria, which allows for a better understanding of the ranking results, as well as for a better comprehension of measuring efficiency from the point of view of productivity. This can be achieved by calculating a Pearson correlation coefficient between the l-distance metrics and each of the input variables. Accordingly, it is essential to establish an order of importance for the input variables. The correlations are presented in Table 2.

Table 2: Variable Importance as measured by Correlation with the I-distance

\begin{tabular}{|l|c|}
\hline Variables & \multicolumn{1}{|c|}{$\begin{array}{c}\text { Correlation with the } \\
\text { I-distance }\end{array}$} \\
\hline Total Income (TI) per employee & $0.934^{\star \star}$ \\
\hline Total Net Income (TNI) per employee & $0.915^{\star \star}$ \\
\hline EBT per employee & $0.912^{\star \star}$ \\
\hline Equity per employee & $0.905^{\star *}$ \\
\hline Assets per employee & $0.871^{\star \star}$ \\
\hline Net Fees and Commissions Income (NF\&Cl) per employee & $0.596^{\star \star}$ \\
\hline Fees and Commissions Income (F\&Cl) per employee & $0.504^{\star \star}$ \\
\hline
\end{tabular}

The most significant variable for evaluating bank efficiency from the standpoint of a bank's productivity is Total Income (TI) per Employee, with $\mathrm{r}=0.934, \mathrm{p}<0.001$, followed by Total Net Income (TNI) per Employee, Earnings Before Tax (EBT) per Employee, Equity per Employee and Assets per Employee. As has been already indicated, all these variables are pertinent to investigation as they can explain the top position held by individual banks. The AlK Bank has vast values of Total Income (TI), Total Net Income (TNI), Earnings Before $\operatorname{Tax}(E B T)$, Equity and Assets, in comparison with the others reviewed. When divided by its number of employees, it is launched even higher in its level of productivity efficiency. The AlK Bank is, therefore, the bank that most certainly has the best productivity results. Similar are the cases of the UniCredit Bank, Banca Intesa, and the Hypo-Alpe-Adria Bank.

In order to provide a complete picture of this particular ranking of Serbian banks, it is interesting to compare the results gained from the research carried out for this paper, with those results that have previously published in other studies concerning the same matter.

Firstly let this study's findings be compared with those of a study conducted by Mihailovic, Bulajic and Savic (2009), who were among the first to publish results obtained from the l-distance method. As has already been elaborated upon in section 1, these authors utilized both the I-distance and DEA method in order to measure bank efficiency and rank them accordingly. The first main difference in regard to this current paper and theirs is reflected in the fact that these authors were driven by the results of the DEA method and chose the input variables of I-distance method as such. The second main difference is that Bulajic and Savic did not examine efficiency from the point of view of productivity, which is the primary goal of the research undertaken in this current paper presented within. If the results of the I-distance methods are compared, it will be seen that those banks that top both methods are relatively the same. Mihailovic et al. (2009) present the AlK Bank ( $1^{\text {st }}$ place in the results here), Raiffeisen Bank (6 $6^{\text {th }}$ place), Delta Bank - today known as Banca Intesa ( $3^{\text {rd }}$ place), Komercijalna Bank (12 ${ }^{\text {th }}$ place) and Vojvodjanska Bank ( $31^{\text {st }}$ place) as those banks that top their ranking. There has been a multitude of changes in the banking sector since their study was initially conducted: certain banks have been liquidated; some of them have changed their name. Bearing this in mind, a Pearson coefficient of correlation between the I-distance metrics used in this paper and the one obtained in the research of Bulajic and Savic has been calculated. The correlation between them is $0.582, p=0.004$, significant at a 0.01 level and demonstrating a strong correlation (Cohen, 1988).

Bulajic et al. (2011) offered a newer perspective on bank efficiency, as they measured it by using the DEA method - one that provides results based on a set of inputs and outputs. Nevertheless, the primary difference between their research and the study presented within is that they utilized a different method based on a different set of criteria. In their paper, the inputs were based on available data for each bank and for every observed year (Bulajic et al., 2011), which entailed: 
- the measure of a bank's operating costs as its fixed asset-to-equity capital ratio;

- the unit price of a bank's current assets as the ratio of annual interest expenses to its total loanable funds;

- the measure of the riskiness of a bank's overall portfolio as a ratio of its provisions to its total assets;

- the measure of a bank's size as its total assets on January the 1st of the observed year;

- a bank's number of employees;

- the number of a bank's branches.

Bulajic et al. also utilized the following outputs:

- a bank's total assets on December the 31st of the observed year (a bank's total assets at the beginning of the year, plus the annual profit/loss as a measure of a bank's business performance);

- a bank's total revenue from the 1st of January to the 31st of December;

- a bank's interest rates' income (a measure for the bank's primary income driver).

Again, the second main difference is that the analysis of Bulajic et al. is focused on the overall measurement of a bank's efficiency, not concerned with the perspective of productivity, unlike the study that is presented in this paper. A comparison of the results gained by Bulajic et al. in this manner and the results of the analysis of the current study of this paper have shown the following banks to top their ranking: Raiffeisen Bank $\left(6^{\text {st }}\right.$ place within the current study's results), the AIK Bank ( $1^{\text {st }}$ place), Banca Intesa ( $3^{\text {rd }}$ place), the Hypo-AlpeAdria Bank ( $4^{\text {th }}$ place), Komercijalna Bank (12 $2^{\text {th }}$ place) and Unicredit Bank ( $2^{\text {nd }}$ place). These results are far more compatible with the results of measuring bank efficiency exclusively from the point of productivity. The Pearson correlation of these was calculated to be $0.647, p<0.000$, indicating a strong correlation (Cohen, 1988). Furthermore, a Spearmen's correlation of these ranks between the two ranking lists has also been calculated, which has given a correlation of $0.642, p<0.000$.

Another study has focused on examining the Serbian banking sector in order to rank Serbian banks. In this study, 14 variables were used as the input: (I) NIM (Net Interest Margin), (II) Equity Ratio, (III) CBNI/CBI (Core Net Business Income/Core Business Income), (IV) ROE (Return on Equity), (V) ROA (Return on Assets), (VI) Active IR (Active Interest Rate), (VII) Net Interest Income, (VIII) CBNI, (IX) CBI, (X) Equity, (XI) Assets, (XII) Loans, (XIII) Deposits and (XIV) Passive IR (Passive Interest Rate). While this study has given a comprehensive analysis of the Serbian banking sector, from a productivity point of view it is far too effusive. In order to examine efficiency from a standpoint of productivity, the research undertaken within the paper presented here has been in-framed, as has been described in Section 2. The top banks here also show excellent performance in the study conducted by Knezevic et al. (2011). However, significant differences are to be found in the Dunav bank. Even though it tops the research results of Knezevic et al., the results obtained for this paper from a point of productivity ranks it at the bottom position. Compared to others from a point of productivity, the Dunav bank is extremely weak in the variables Total Income (TI) and Total Net Income (TNI) per Employee, while EBT and Equity per employee are found to be significantly less than in other banks. This is why the Pearson correlation between the study and the current I-distance measure is 0.265 . Moreover, it is also insignificant, showing a weak connection between these two measures. Nevertheless, the Spearman's rho has been calculated to be $0.454, p=0.008$.

The accelerated development of banking capacities has not been followed by a visible growth in productivity in Serbian domestic banks. According to the productivity indicators applied in the research into structural changes and performance of the Serbian banking sector, it has been observed that Serbia belongs to the most underdeveloped countries in Europe (Vukovic, 2009). In this regard, the importance of the comparison of productivity with a reference group of countries is emphasized in relation to the mere testing of the productivity of the banks within one country and their subsequent ranking. In this study, a methodology of the European Central Bank and the European Bank for Reconstruction and Development has been used, which represents an adequate basis for comparison with different groups of European countries. Additionally, the following indicators have been used in this study as critical indicators of productivity in banking: assets, deposits and loans per employee. By observing productivity per employee, the research has shown that the Serbian banking sector has lower assets in relation to the EU countries. 
The purpose of this study is to perform a ranking of banks according to the efficiency in terms of productivity at which key financial variables and the number of bank employees were used. There are studies where the economic variables in financial and operational accounting records are used. For example Mandić et al. (2014) applied the fuzzy AHP and TOPSIS methods to analyze financial parameters of Serbian banks. In the paper of Knezevic et al. (2012), where the DEA method was applied, it is pointed out that one of the fundamental principles is the principle of efficiency, and it is emphasized that, for developing countries, it is particularly important to monitor the efficiency of banks and compare it with countries in the region. Yang (2009) presented the evaluation of 240 branches of one big Canadian bank using the Data Envelopment Analysis (DEA), and the traditional performance ratios (an operational efficiency model, a production approach) were used.

The technical and allocative efficiency of a bank constitutes the measure in the sum of its overall economic efficiency. Taking the ranks that have been obtained in this study into consideration, it can be seen that the AlK Bank, the UniCredit Bank, Banca Intesa, the Hypo-Alpe-Adria Bank and Raiffeisen Bank achieve particularly good results in this efficiency field. Considering the selected key financial parameters, this would suggest that their management effectively governs the operations of their banks in the Serbian banking market and that they are the strongest from the standpoint of productivity.

When compared to previous study results obtained by Mihailovic et al. (2009), it can be noted that the best players remain similar (AIK Bank, Raiffeisen Bank, Banca Intesa); however, the situation is quite different in regard to Komercijalna Bank and Vojvodjanska bank. This is a very interesting conclusion and shall be the future course of subsequent research undertaken by the authors of this paper. Nevertheless, Bulajic et al. (2011) show similar results, where these same banks (Raiffeisen Bank, AlK Bank, Banca Intesa, Hypo-Alpe-Adria Bank and Unicredit Bank) score the best results while Komercijalna Bank remains under a cloud.

One of the most important contributions of this paper is the ability of its method to single out those variables which most influence bank efficiency from the perspective of productivity, taking into account the very order of their importance; such variables are Total Income per Employee, Total Net Income per Employee, EBT per Employee, Equity per Employee and Asset per Employee. The future course of research by this paper's authors will also further examine these.

To monitor and measure productivity, it is logical to use those financial ratios that best reflect both the actual relationship between the achieved financial performances of a bank's employees and the average number of its employees. Merely using a bank's total assets or its assets financed by equity does not provide the clearest picture possible of the bank market. Employees achieve outputs in the form of profits and total revenues with lower or higher levels of economic efficiency and, within that, they increase productivity; hence the exact reason as to why it is quite necessary to switch the entirety of the observing aspect to the perspective of bank productivity.

For future research, it would be useful that the productivity of the Serbian banking sector be compared to productivity in other countries within the reference group.

\section{REFERENCES}

[1] Andries, A.M. (2011). The Determinants of Bank Efficiency and Productivity Growth in the Central and Eastern European Banking Systems. Eastern European Economics, 49(6), 38-59. doi:10.2753/EEE00128775490603

[2] Avkiran, N. K. (1995). Developing an instrument to measure customer service quality in branch banking. International Journal of Banks Marketing, 12(6), 10-18. doi:10.1108/02652329410063223

[3] Benkovic, S., \& Dobrota, M. (2012). Application of teaching methods and techniques at Serbian Universities: progress over time. Management, 16(63), 35-43. doi:10.7595/management.fon.2012.0007

[4] Bulajic, M., Savic, G., Savic S., Mihailovic, N., \& Martic, M. (2011). Efficiency assessment of banks in Serbia, Technics Technologies Education Management, 6(3), 657-662.

[5] Bulajic, M., Savic, S. \& Savic, G. (2012). Analysis of competition in banking sector of Serbia. Actual Problems of Economics, 134(8), 330-338. 
[6] Caraiani, P. (2011). Comparing monetary policy rules in the Romanian economy: a new Keynesian approach. Romanian Journal of Economic Forecasting, 14(4), 30-46.

[7] Chiorazzo, V., \& Milani, C. (2011). The impact of taxation on bank profits: Evidence from EU banks. Journal of Banking and Finance, 35(12), 3202-3212. doi:10.1016/j.jbankfin.2011.05.002

[8] Claessens, S., \& van Horen, N. (2012). Being a foreigner among domestic banks: Asset or liability? Journal of Banking and Finance, 36(5), 1276-1290. doi:10.1016/j.jbankfin.2011.11.020

[9] Cohen, J. (1988). Statistical power analysis for the behavioral sciences (2nd ed.). New Jersey: Lawrence Erlbaum.

[10] Dekker, D., \& Post, T. (2001). A quasi-concave DEA model with an application for bank branch performance evaluation, European Journal of Operational Research, 132(2), 296-311. doi:10.1016/S03772217(00)00153-3

[11] Dobrota, M., Jeremic, V., \& Markovic, A. (2012). A new perspective on the ICT Development Index. Information Development, 28(4), 271-280. doi:10.1177/0266666912446497

[12] Dobrota, M., Bulajic, M., Bormnann, L., \& Jeremic, V. (in press). A New Approach to QS University Ranking Using Composite I-distance Indicator: Uncertainty and Sensitivity Analyses. Journal of the Association for Information Science and Technology, in press.

[13] Festic, M., \& Kavkler, A. (2012). The roots of the banking crisis in the new eu member states: A panel regression approach. Romanian Journal of Economic Forecasting, 15(1), 20-40.

[14] Fiordelisi, F., \& Molyneux, P. (2010). Total factor productivity and shareholder returns in banking, Omega, 38(5), 241-253. doi:10.1016/j.omega.2008.07.009

[15] Fixler, D., \& Zieschang, K. (1999). The productivity of the banking sector integrating financial and production approaches to measuring financial service output, Canadian Journal of Economics, 32(2), 547569.

[16] Hadad, M.D., Hall, M.J.B., Kenjegalieva, K.A., Santoso, W., \& Simper, R. (2012). A new approach to dealing with negative numbers in efficiency analysis: An application to the Indonesian banking sector. Expert Systems with Applications, 39(9), 8212-8219. doi:10.1016/j.eswa.2012.01.145

[17] Horvat, A., Dobrota, M., Krsmanovic, M., \& Cudanov, M. (2013). Student perception of Moodle learning management system: a satisfaction and significance analysis. Interactive Learning Environments, (ahead-of-print), 1-13. DOI:10.1080/10494820.2013.788033

[18] Houston, J., Lin, C., Lin, P., \& Ma, Y. (2010). Creditor rights, information sharing and bank risk taking. Journal of Financial Economics, 96, 485-512.

[19] Huang, T.H., Chiang, L.C., \& Chen, K.C. (2011). An Empirical Study of Bank Efficiencies and Technology Gaps in European Banking. Manchester School, 79(4), 839-860. doi:10.1111/j.14679957.2010.02178.x

[20] Isljamovic, S., Jeremic, V., Petrovic, N., \& Radojicic, Z. (2014). Colouring the socio-economic development into green: I-distance framework for countries' welfare evaluation, Quality \& Quantity, doi:10.1007/s11135-014-0012-0

[21] Ivanovic, B. (1973). A method of establishing a list of development indicators. Paris: United Nations educational, scientific and cultural organization.

[22] Ivanovic, B. (1977). Classification Theory. Belgrade: Institute for Industrial Economic.

[23] Ivanovic, B., \& Fanchette, S. (1973). Grouping and ranking of 30 countries of Sub-Saharan Africa, Two distance-based methods compared. Paris: United Nations educational, scientific and cultural organization.

[24] Jeremic, V., Markovic, A., \& Radojicic, Z. (2011). ICT as crucial component of socio-economic development. Management, 16(60), 5-9.

[25] Jeremic, V., Jovanovic-Milenkovic, M., Martic, M., \& Radojicic, Z. (2013). Excellence with Leadership: the crown indicator of SCImago Institutions Rankings IBER Report. El Profesional de la Informacion, 22(5), 474-480.

[26] Jeremic, V., \& Jovanovic-Milenkovic, M. (2014). Sustainable Development in the e-Health Sector of the European Union. Current Science, 106(12), 1647-1653.

[27] Jovanovic, M., Jeremic, V., Savic, G., Bulajic, M., \& Martic, M. (2012). How does the normalization of data affects the ARWU ranking? Scientometrics, 93(2), 319-327. doi: 10.1007/s11192-012-0674-0.

[28] Jovanovic-Milenkovic, M., Jeremic, V., \& Martic, M. (2014). Sustainable Development in the E-Health 
Sector of the European Union. Journal of Environmental Protection and Ecology, 15(1), 248-256.

[29] Kasman, A., Kasman, S., \& Turgutlu, E. (2011). Testing Profit and Structure Relationship in the European Banking Markets Using Efficiency Measures. Developing Economies, 49(4), 404-428. doi:10.1111/j.1746-1049.2011.00145.x

[30] Kirikal, L. (2005). Stabilisation Period and Malmquist Index of Productivity Change: An Empirical Study of Estonian Banks, In: Papers of the 4th International Symposium of DEA: Data Envelopment Analiysis and Performance Management, Birmngham, UK, pp. 353-360.

[31] Knezevic, S., Barjaktarevic-Rakocevic, S., \& Djuric, D. (2011). General Financial Reporting and Special-Purpose Reports of Banks. Management, 16(59), 5-14.

[32] Knežević, S., Marković, M., \& Barjaktarović Rakočević, S. (2012), Assessing Efficiency in Banking, Industry - Journal of the Institute of Economics in Belgrade, 40(3),71-92.

[33] Koutsomanoli-Filippaki, A., Margaritis, D., \& Staikouras, C. (2012). Profit efficiency in the European Union banking industry: a directional technology distance function approach. Journal of Productivity Analysis, 37(3), 277-293. doi:10.1007/s11123-011-0261-z

[34] Liu, S. (2009). Slacks-based efficiency measures for predicting bank performance, Expert Systems with Applications, 36(2), 2813-2818. doi:10.1016/j.eswa.2008.01.032

[35] Maggi, B., \& Guida, M. (2011). Modelling non-performing loans probability in the commercial banking system: efficiency and effectiveness related to credit risk in Italy. Empirical Economics, 41(2), 269-291, doi:10.1007/s00181-010-0379-2

[36] Mihailovic, N., Bulajic, M., \& Savic, G. (2009). Ranking of banks in Serbia. YUJOR, 19(2), 323-334. doi:10.2298/YUJOR0902323M

[37] Mandić, K., Delibašić, B., Knežević, S., \& Benković, S. (2014). , Economic Modelling, 43, 30-37.

[38] Olson, D., \& Zoubi, T.A. (2011). Efficiency and bank profitability in MENA countries. Emerging Markets Review, 12(2), 94-110. doi:10.1016/j.ememar.2011.02.003

[39] Paradi, C.J., Rouatt, S., \& Haiyan, Z. (2011). Two-stage evaluation of bank branch efficiency using data envelopment analysis, Omega, 39(1), 99-109. doi:10.1016/j.omega.2010.04.002

[40] Park, K.S., \& Cho, J.W. (2011). Data speak more than technical efficiency. EUROPEAN Journal of Operational Research, 215(1), 301-308. doi:10.1016/j.ejor.2011.05.004

[41] Primorac, M., \& Troskot, Z. (2005). Mjerenje efikasnosti i produktivnosti hrvatskih banaka Malmquistovim indeksom promjene ukupne faktorske produktivnosti, Financijska teorija i praksa, 29(4), 367-383, in Croatian.

[42] Radojicic, Z., \& Jeremic, V. (2012). Quantity or quality: What matters more in ranking higher education institutions? Current Science, 103(2), 158-162.

[43] Roghanian, P., Rasli, A., \& Gheysari, H. (2012). Productivity Through Effectiveness and Efficiency in the Banking Industry, Procedia - Social and Behavioral Sciences, 40, 550-556. doi:10.1016/j.sbspro.2012.03.229

[44] Seke, K., Petrovic, N., Jeremic, V., Vukmirovic, J., Kilibarda, B., \& Martic, M. (2013). Sustainable development and public health: rating European countries. BMC Public Health, 13(77), 1-7. doi:10.1186/1471-2458-13-77

[45] Shin, D.J., \& Kim, B.H.S. (2011). Efficiency of the Banking Industry Structure in Korea. Asian Economic Journal, 25(4), 355-373. doi:10.1111/j.1467-8381.2011.02066.x

[46] Tecles, P.L., \& Tabak, B.M. (2010). Determinants of bank efficiency: The case of Brazil. European Journal of Operational Research, 207(3), 1587-1598. doi:10.1016/j.ejor.2010.06.007

[47] Uludag, B.K., \& Gokmen, H. (2011). Testing the Profitability of Turkish Banking Industry with Dynamic Approach. Iktisat Isletme Ve Finans, 26(308), 71-98. doi:10.3848/iif.2011.308.3191

[48] Vukovic,V., 2009. Strukturne promene i performanse bankarstva Srbije 2002-2008, Institut ekonomskih nauka, Beograd, 119-134, in Serbian.

[49] Wu, D.D., Yang, Z., \& Liang, L. (2006). Efficiency analysis of cross-region bank branches using fuzzy data envelopment analysis, Applied Mathematics and Computation, 181(1), 271-281. doi:10.1016/j.amc.2006.01.037

[50] Wu, J., Luca, A.C., \& Jeon, B.N. (2011). Foreign bank penetration and the lending channel in emerging economies: Evidence from bank-level panel data. Journal of International Money and Finance, 30(6), 1128-1156. doi:10.1016/j.jimonfin.2011.05.011 
[51] Yudistira, D. (2003). Efficiency in Islamic Banking an Empirical Analysis of Eighteen Banks, Islamic Economic Studies, 12(1), 1-19.

[52] Yang, Z. (2009). Bank Branch Operating Efficiency: A DEA Approach, Proceedings of the International MultiConference of Engineers and Computer Scientists 2009 Vol II IMECS, March 18 - 20, 2009, Hong Kong.

[53] Zhang, J.H., Wang, P., \& Qu, B.Z. (2012). Bank risk taking, efficiency and law enforcement: Evidence from Chinese city commercial banks. China Economic Review, 23(2), 284-295. doi:10.1016/j.chieco.2011.12.001

Receieved: September 2014. Accepted: May 2015.

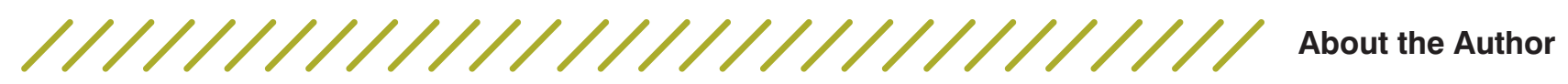

$$
\begin{array}{r}
\text { Veljko Dmitrović } \\
\text { University of Belgrade, Faculty of Organizational Sciences } \\
\text { dmitrovicv@fon.bg.ac.rs }
\end{array}
$$

Veljko Dmitrović works at the Faculty of Organizational Sciences, University of Belgrade, at the Department of Financial Management and Accounting. He is completing his PhD studies at the Faculty of Organizational Sciences. He achieved his MSc degree in Financial Management at the Faculty of Organizational Sciences, University of Belgrade, and his BSc and MA degrees in Marketing Management at the Faculty of Economics in Subotica, University of Novi Sad. So far he has authored and coauthored more than 50 pa-

pers published in international and national journals and conferences. He has been involved in several research projects. Before the academic career he gained practical experience working for five years in "Fidelinka" a.d., Subotica.

\section{Marina Dobrota \\ University of Belgrade, Faculty of Organizational Sciences dobrota.marina@fon.bg.ac.rs}

Marina Dobrota works as a teaching assistant at the Faculty of Organizational Sciences, University of Belgrade, Serbia. She completed her PhD studies at the Faculty of Organizational Sciences. Her major professional interests are applied statistics, composite indicators, ICT development strategy, data mining in medicine, and biostatistics. She published more than 30 articles in scientific journals and conferences. She reviewed several papers in scientific journals in SSCl and SCl-e.

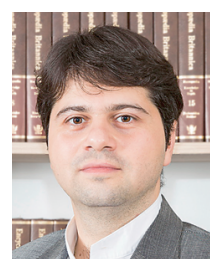

Snežana Knežević

Faculty of Organizational Science,University of Belgrade knezevic.snezana@fon.bg.ac.rs

Snežana Knežević was born in 1966 in Pančevo (Jabuka), where she graduated from the school of economics. She graduated from the Faculty of Economics in Belgrade where she also got her MSc degree. She got her PhD degree at the Faculty of Organizational Sciences in Belgrade. The areas of her scientific interest are Finance,
Accounting and Environmental protection. She is fluent in French and English. She has

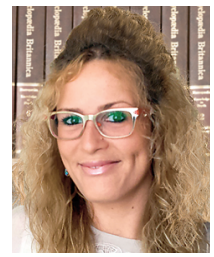
published several monographs and papers of scientific and professional orientation in the country and abroad. Currently, she works at the Faculty of Organizational Sciences in Belgrade, Department of Financial Management. She is an associate member of the Scientific Society Of Economists and a member ot the EUMMAS (EuropeanMarketing and Management Association). 